\title{
Dermatological complications of the cupping procedure
}

\section{Dermatologiczne powikłania zabiegu stawiania baniek}

\author{
Paulina A. Szczepanik-Kułak, Michał Adamczyk, Dorota Krasowska
}

Department of Dermatology, Venereology and Pediatric Dermatology, Medical University of Lublin, Lublin, Poland

Katedra i Klinika Dermatologii, Wenerologii i Dermatologii Dziecięcej, Uniwersytet Medyczny w Lublinie, Polska

CORRESPONDING AUTHOR/ ADRES DO KORESPONDENCJI: lek. Paulina A. Szczepanik-Kułak Katedra i Klinika Dermatologii, Wenerologii i Dermatologii Dziecięcej

Uniwersytet Medyczny

w Lublinie

tel.: +48 889987497

e-mail: vpaulinav@gmail.com

\begin{abstract}
Introduction: Cupping is a method known since prehistoric times. Currently, due to the lack of scientific evidence confirming the effectiveness of cupping therapy, it is perceived as a controversial element of alternative medicine. The mechanism of action of this method has not been fully understood but the method is considered relatively safe. Most of the side effects are mild to moderate in severity, and they are usually associated with blood cupping.
\end{abstract}

Objective: To present the side effect in the form of numerous blisters on the skin of the back where cups had been applied, and to discuss the cutaneous complications of this therapeutic method.

Case report: We present the case of an 85-year-old woman in whom cupping was applied as remedy for respiratory disorders. The procedure with the use of fire bubbles was carried out by a friend. After removing cups from the skin, in the place of their adherence, vivid red and purple-colored swollen areas were observed, accompanied by numerous small blisters with a well-tensed cover, filled with serous fluid. The applied local treatment resulted in clinical improvement.

Conclusions: The presented case illustrates the risk of side effects of cupping. The procedure was performed in an elderly patient by an unqualified person, without following the basic rules of asepsis. Rapid and appropriate therapeutic intervention allowed resulted in improvement.

\section{STRESZCZENIE}

Wprowadzenie: Stawianie baniek to metoda terapeutyczna znana od czasów prehistorycznych. Obecnie z uwagi na brak dowodów naukowych potwierdzających skuteczność terapii bańkami jest postrzegana jako kontrowersyjny element medycyny niekonwencjonalnej. Mechanizm działania omawianej metody nie został do końca poznany, ale jest ona uważana za względnie bezpieczną. Większość działań niepożądanych ma łagodne lub umiarkowane nasilenie i zazwyczaj dotyczą one zabiegów z wykorzystaniem baniek ciętych.

Cel pracy: Przedstawienie działania niepożądanego w postaci licznych pęcherzy na skórze pleców w miejscu stawiania baniek oraz omówienie dermatologicznych powikłań tej metody terapeutycznej.

Opis przypadku: $Z$ powodu utrzymujących się zaburzeń oddechowych zalecono 85-letniej pacjentce terapię bańkami. Zabieg z wykorzystaniem baniek ogniowych przeprowadził przyjaciel rodziny. Po usunięciu szklanych naczyń ze skóry, w miejscu ich przylegania, zaob- 
serwowano żywoczerwone i sinofioletowe, obrzęknięte pola, którym towarzyszyły liczne, drobne pęcherze o dobrze napiętej pokrywie, wypełnione płynem surowiczym. Zastosowanym leczeniem miejscowym uzyskano poprawę kliniczną.

Wnioski: Przedstawiony przypadek ilustruje ryzyko rozwoju działań niepożądanych stawiania baniek. Zabieg został wykonany u pacjentki w wieku podeszłym przez osobę niewykwalifikowaną, bez zachowania podstawowych zasad aseptyki. Szybka i odpowiednia interwencja terapeutyczna pozwoliła na uzyskanie poprawy klinicznej.

Key words: cupping therapy, complementary medicine, skin complications.

Słowa kluczowe: stawianie baniek, medycyna niekonwencjonalna, powikłania skórne.

\section{INTRODUCTION}

Cupping is a therapeutic method known since prehistoric times. Currently, due to the lack of scientific evidence confirming the effectiveness of cupping therapy, it is perceived as a controversial element of alternative medicine [1]. According to the definition of the World Health Organization (WHO), the cupping procedure is based on the local effect of negative pressure created in an airtight vessel placed directly on the skin [2]. There are several classifications based on the treatment technique and equipment used. The selection of the treated area depends on the location of a specific ailment. Most often it is the upper part of the back [3].

Cupping is considered a relatively safe procedure. Most of the side effects are mild to moderate in severity, and they usually relate to blood cupping [4]. Immediately after the therapy, erythematous and edema lesions limited to the adhesion area of a cup are often observed, as well as ecchymoses resulting from vasodilatation and rupture of skin blood vessels $[4,5]$. Sometimes secondary scars occur due to local burns. Other side effects include headache, dizziness, itching, fatigue, muscle tightness and stiffness, anemia, nausea, development of blisters and hematomas on the skin, discoloration, local pain, abscess formation, skin infections, insomnia and vasovagal syncope [6].

\section{OBJECTIVE}

To present the side effect in the form of numerous blisters on the skin of the back where cups had been applied to the patient's skin, and to discuss cutaneous complications of this therapeutic method.

\section{WPROWADZENIE}

Stawianie baniek to metoda terapeutyczna znana od czasów prehistorycznych. Z powodu braku dowodów naukowych potwierdzających skuteczność terapii bańkami jest postrzegana jako kontrowersyjny element medycyny niekonwencjonalnej [1]. Zgodnie z definicją Światowej Organizacji Zdrowia (World Health Organization - WHO) stawianie baniek polega na miejscowym działaniu podciśnienia wytworzonego w hermetycznym naczyniu przyłożonym bezpośrednio do skóry [2]. Istnieje kilka klasyfikacji uwzględniających technikę wykonywania zabiegów oraz wykorzystywanych urządzeń. Dobór okolicy poddawanej zabiegom zależy od lokalizacji określonej dolegliwości. Najczęściej jest to skóra pleców [3].

Terapia z zastosowaniem baniek jest uważana za względnie bezpieczną procedurę. Większość działań niepożądanych ma łagodne lub umiarkowane nasilenie i zazwyczaj dotyczą one zabiegów z wykorzystaniem baniek ciętych [4]. Bezpośrednio po terapii często obserwuje się ograniczone do pola przylegania bańki zmiany rumieniowe, obrzękowe oraz wybroczyny wynikające z wazodylatacji i pękania skórnych naczyń krwionośnych [4,5]. Niekiedy dochodzi do powstania blizn wtórnych do miejscowego oparzenia. Do pozostałych działań niepożądanych należą: bóle i zawroty głowy, świąd, zmęczenie, napięcie i sztywność mięśni, niedokrwistość, nudności, rozwój pęcherzy i krwiaków na skórze, przebarwienia, miejscowe dolegliwości bólowe, tworzenie ropni, infekcje skórne i omdlenia wazowagalne [6].

\section{CEL PRACY}

Przedstawienie działania niepożądanego w postaci licznych pęcherzy na skórze pleców w miejscu sta- 


\section{CASE REPORT}

A 85-year-old female patient with a history of arterial hypertension was consulted by her family doctor due to a wet cough with sparse expectoration lasting for about 2 weeks. In the patient's back, 12 glass cups were placed asymmetrically on the skin of the back. After their removal, in the place of their adherence, vivid red and purple-purple swollen areas were observed, accompanied by numerous small blisters with welltensed cover, filled with serous fluid (figs. $1 \mathrm{~A}, \mathrm{~B}$ ). The patient denied pain and felt good. On an emergency basis, she was consulted by a dermatologist who recommended piercing the blisters and using hydrocortisone and oxytetracycline hydrochloride in an aerosol, and a cream containing zinc oxide, sucralfate, copper sulphate, zinc sulphate and allantoin. In addition, he pointed to the need to keep the lesions clean and to use sterile dressings, changed several times a day. The changes were quickly resorbed and the skin was gradually healing (figs. $1 \mathrm{C}$, D). Post-inflammatory hyperpigmentation was observed after 3 weeks (figs. 1 E, F).

\section{DISCUSSION}

Currently, there is only low-quality evidence of the therapeutic effectiveness of cupping.

Undoubtedly, the frequency of side effects of cupping may be significantly underestimated. This is due to the small number of clinical trials addressing this issue. In addition, the cupping procedure is usually done at home. Results of a systematic review by Kim et al. indicated that postoperative complications were wiania baniek u pacjentki oraz omówienie skórnych powikłań tej metody terapeutycznej.

\section{OPIS PRZYPADKU}

Pacjentka, lat 85, z dodatnim wywiadem nadciśnienia tętniczego, z powodu utrzymującego się od około 2 tygodni wilgotnego kaszlu ze skąpym odkrztuszaniem bez innych dolegliwości w badaniu przedmiotowym i podmiotowym została skonsultowana przez lekarza rodzinnego, który zalecił terapię z zastosowaniem baniek. U pacjentki na skórze pleców niesymetrycznie przyłożono 12 baniek szklanych. Po ich usunięciu, w miejscu ich przylegania, zaobserwowano żywoczerwone i sinofioletowe, obrzęknięte pola, którym towarzyszyły liczne, drobne pęcherze o dobrze napiętej pokrywie, wypełnione płynem surowiczym (ryc. 1 A, B). Pacjentka negowała dolegliwości bólowe. $W$ pilnym trybie ambulatoryjnie została skonsultowana przez dermatologa, który zalecił przekłucie pęcherzy i zastosowanie hydrokortyzonu i chlorowodorku oksytetracykliny w aerozolu oraz kremu zawierającego tlenek cynku, sukralfat, siarczan miedzi, siarczan cynku i alantoinę. Ponadto zalecił stosowanie jałowych opatrunków, zmienianych kilkakrotnie w czasie doby. Zmiany uległy szybkiej resorpcji, a skóra stopniowemu gojeniu (ryc. 1 C, D). Po 3 tygodniach obserwowano przebarwienia pozapalne (ryc. $1 \mathrm{E}, \mathrm{F}$ ).

\section{OMÓWIENIE}

Obecnie dostępne są jedynie dowody naukowe o niskiej jakości, wskazujące na efektywność terapeutyczną zabiegów stawiania baniek.

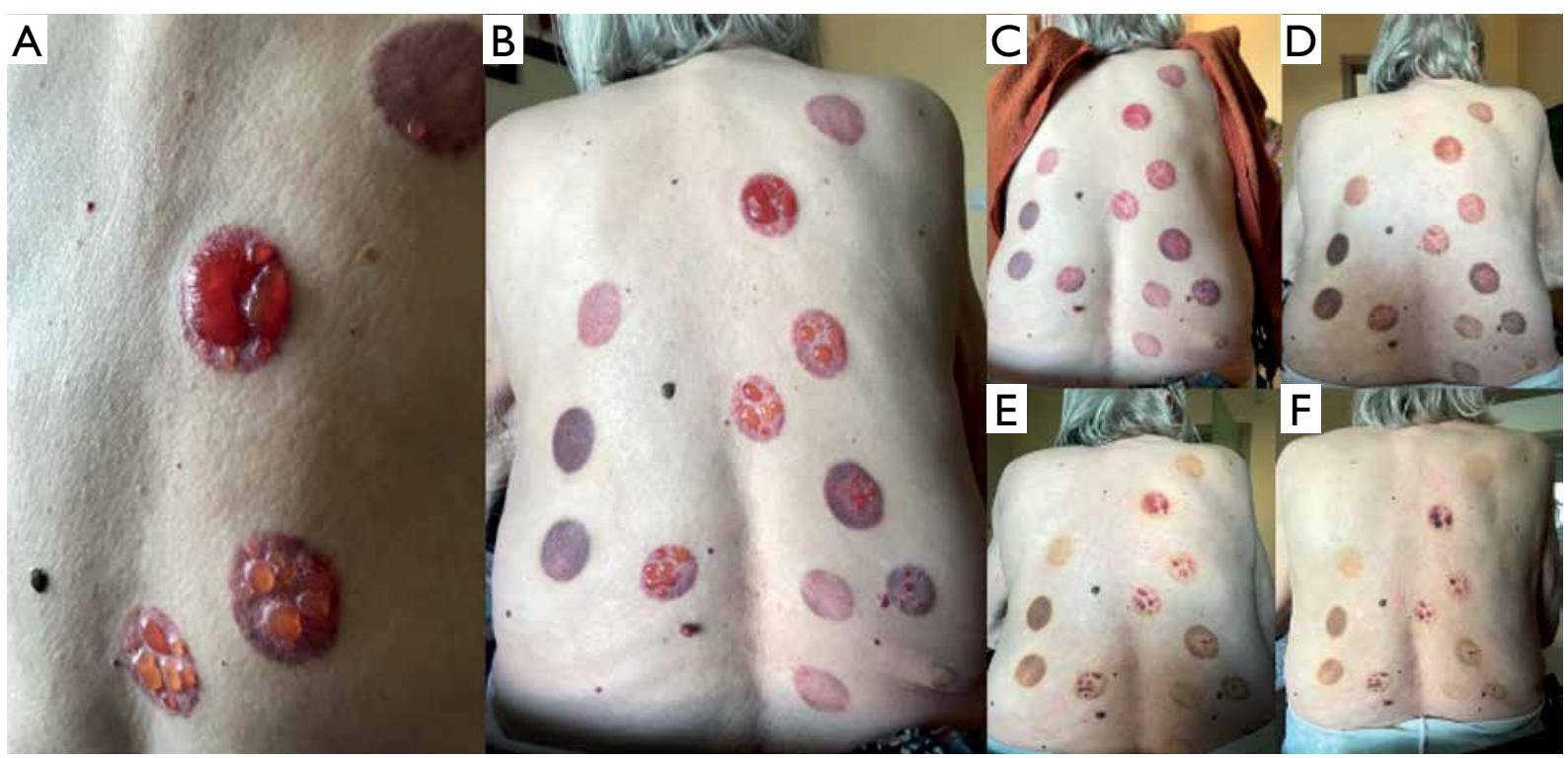

Figure I. Oval-shaped, erythematous, blue-colored lesions and blisters visible on the patient's skin at places where cups had been applied $(A, B)$. Followed by gradual evolution of eruptions (C, D) and skin healing $(E, F)$

Rycina I. Widoczne na skórze w miejscach przystawienia baniek owalnego kształtu zmiany rumieniowe, sinofioletowe oraz pęcherze (A, B). Następnie stopniowa ewolucja zmian (C, D) i gojenie skóry (E, F) 
rare [7]. In observational studies, anemia, panniculitis, and herpes virus infections were the most commonly reported. It was noticed that the factors increasing the risk of developing complications included: performing the procedure by a person without appropriate competences, using the therapy for too long, and using wet cups [7]. Similar conclusions were presented by Al-Bedah et al., who reviewed scientific reports published in the years 2000-2016 on the safety of cupping therapy. They showed that most of the side effects were shortterm. The most common complications were: scarring, burns, headache, local and generalized pruritus, dizziness, fatigue, somnolence, increased pain, increased muscle tone, anemia, nausea, blistering, local hematomas, abscesses, skin infections caused by herpes simplex virus or mycobacteria, insomnia, stroke, cellulitis, acquired hemophilia, lipomas, hyperpigmentation, vasovagal syncope [6]. Mehta et al. noted that the type of complications depended on the type of cups, method of their application and frequency of procedures [5]. Iblher et al. described the risk of developing burns after placing fire bubbles and a subsequent necessity to undertake plastic surgery. This complication depends on the treatment technique used [8]. The literature emphasizes the necessity of preserving asepsis during treatments [9]. It is worth emphasizing that in the conducted randomized clinical trials, in which asepsis was followed during cupping therapy, no adverse effects were found $[10,11]$.

\section{CONCLUSIONS}

The presented case confirms the risk of developing side effects of cupping. Rapid and appropriate therapeutic intervention allowed for clinical improvement.

\section{CONFLICT OF INTEREST}

The authors declare no conflict of interest.
Niewątpliwie częstość występowania działań niepożądanych terapii bańkami może być znacznie zaniżona. Wynika to z niewielkiej liczby badań klinicznych, które podejmowałyby to zagadnienie. Ponadto procedura stawiania baniek przeważnie wykonywana jest $\mathrm{w}$ warunkach domowych. Wyniki przeglądu systematycznego dokonanego przez Kim i wsp. wykazały, że powikłania pozabiegowe występują rzadko [7]. W badaniach obserwacyjnych najczęściej odnotowywano niedokrwistość, zapalenie tkanki podskórnej oraz infekcje wirusami opryszczki. Zauważono, że do czynników zwiększających ryzyko rozwoju powikłań należą: wykonywanie zabiegu przez osoby nieprzeszkolone, stosowanie terapii przez zbyt długi czas oraz korzystanie $\mathrm{z}$ baniek mokrych [7]. Podobne wnioski przedstawili Al-Bedah i wsp., którzy dokonali przeglądu doniesień naukowych opublikowanych w latach 2000-2016 dotyczących bezpieczenstwa stosowania terapii bańkami. Autorzy stwierdzili, że większość działań niepożądanych miała charakter krótkotrwały. Najczęściej występującymi miejscowymi powikłaniami były: tworzenie pęcherzy, krwiaki, ropnie, zakażenia skóry wywołane przez wirusy opryszczki zwykłej lub mykobakterie, oparzenia, świąd oraz powstawanie blizn. Opisywano również liczne dolegliwości ogólne [6]. Mehta i wsp. zwrócili uwagę, że rodzaj powikłań zależy od rodzaju baniek, metody ich aplikacji oraz częstości przeprowadzania zabiegów [5]. Iblher i wsp. opisali ryzyko rozwoju oparzeń po stawianiu baniek ogniowych oraz późniejszą konieczność podejmowania działań z zakresu chirurgii plastycznej. Powikłanie zależy od zastosowanej techniki zabiegu [8]. W literaturze podkreśla się konieczność zachowania aseptyki w czasie zabiegów [9]. Warto podkreślić, że w przeprowadzonych badaniach klinicznych z randomizacją, w których stosowano się do zasad aseptyki, nie stwierdzono występowania działań niepożądanych $[10,11]$.

\section{WNIOSKI}

Przedstawiony przypadek potwierdza ryzyko rozwoju działań niepożądanych stawiania baniek. Szybka i odpowiednia interwencja terapeutyczna pozwoliła na uzyskanie poprawy klinicznej.

\section{KONFLIKT INTERESÓW}

Autorzy nie zgłaszają konfliktu interesów.

\section{References \\ Piśmiennictwo}

1. Klimasz K., Zhao J.C., Zeng K., Tomasik P.J.: History of cupping. Med Og Nauk Zdr 2018, 24, $244-250$.

2. Acupuncture and Moxibustion: Cupping. [In:] WHO International Standard Terminologies on Traditional Medicine in the Western Pacific Region. WHO Library Cataloguing in Publication Data, Switzerland, Geneva, 2007, $254-255$.

3. Yoo S.S., Tausk F.: Cupping: east meets west. Int J Dermatol 2004, 43, 664-665.

4. Chi L.M., Lin L.M., Chen C.L. Wang S.F., Lai H.L., Peng T.C.: The effectiveness of cupping therapy on relieving chronic neck and shoulder pain: a randomized controlled trial. Evid Based Complement Alternat Med 2016, $2016,7358918$. 
5. Mehta P., Dhapte V.: Cupping therapy: a prudent remedy for a plethora of medical ailments. J Tradit Complement Med 2015, $5,127-134$

6. Al-Bedah A.M., Shaban T., Suhaibani A., Gazzaffi I., Khalil M., Qureshi N.A.: Safety of cupping therapy in studies conducted in twenty one century: a review of literature. Br J Med Res 2016, 15, 1-12.

7. Kim T.H., Kim K.H., Choi J.Y., Lee M.S.: Adverse events related to cupping therapy in studies conducted in Korea: a systematic review. Eur J Integr Med 2013, 6, 434-440.

8. Iblher N., Stark B.: Cupping treatment and associated burn risk: a plastic surgeon's perspective. J Burn Care Rehabil 2007, 28, 355-358.

9. Kim T.H., Kang J.W: A good policy for guaranteed safe practice of complementary and alternative medicine, usage of disposable cupping cups. Evid Based Complement Altern Med 2015, 2015, 970327.

10. Al-Bedah A., Khalil M., Elolemy A., Hussein A.A., Al Qaed M., Al Mudaiheem A., et al.: The use of wet cupping for persistent nonspecific low back pain: randomized controlled clinical trial. J Altern Complement Med 2015, 21, 504-508.

11. Kim J.I., Kim T.H., Lee M.S., Kang J.W., Kim K.H., Choi J.Y., et al.: Evaluation of wet cupping therapy for persistent non-specific low back pain: a randomised, waiting-list controlled, open-label, parallel-group pilot trial. Trials 2011, 12, 146.

Received: 16.10 .2020

Accepted: 5.06 .2021

Otrzymano: $16.10 .2020 \mathrm{r}$

Zaakceptowano: 5.06.2021 r.

How to cite this article:

Szczepanik-Kułak P.A., Adamczyk M., Krasowska D.: Dermatological complications of the cupping procedure. Dermatol Rev/ Przegl Dermatol 2021, 108, 213-217. DOI: https://doi.org/10.5114/dr.2021.108610. 